\title{
Managing the Internalisation Process
}

\section{A Theoretical Perspective}

\author{
Petersen, Bent; Welch, Lawrence S.; Benito, Gabriel R.G.
}

Document Version

Final published version

Publication date:

2008

\section{License \\ CC BY-NC-ND}

Citation for published version (APA):

Petersen, B., Welch, L. S., \& Benito, G. R. G. (2008). Managing the Internalisation Process: A Theoretical

Perspective. Center for Strategic Management and Globalization. SMG Working Paper No. 7/2008

Link to publication in CBS Research Portal

\section{General rights}

Copyright and moral rights for the publications made accessible in the public portal are retained by the authors and/or other copyright owners and it is a condition of accessing publications that users recognise and abide by the legal requirements associated with these rights.

\section{Take down policy}

If you believe that this document breaches copyright please contact us (research.lib@cbs.dk) providing details, and we will remove access to the work immediately and investigate your claim. 


\title{
Managing the Internalisation Process \\ - A Theoretical Perspective
}

\author{
Bent Petersen \\ Lawrence S. Welch \\ Gabriel R.G. Benito
}

SMG WP 7/2008

February 27, 2008 
SMG Working Paper No. 7/2008

February 27, 2008

ISBN: 978-87-91815-20-1

Center for Strategic Management and Globalization Copenhagen Business School

Porcelænshaven 24

2000 Frederiksberg

Denmark

www.cbs.dk/smg 


\title{
Managing the Internalisation Process - A Theoretical Perspective
}

\author{
Bent Petersen* \\ Center for Strategic Management and Globalization \\ Copenhagen Business School \\ Porcelaenshaven 24 \\ 2000 Frederiksberg, Denmark \\ bp.smg@cbs.dk \\ Lawrence S. Welch \\ Melbourne Business School, University of Melbourne \\ 200 Leicester Street \\ Carlton, Victoria 3053, Australia \\ 1.welch@mbs.edu \\ Gabriel R.G. Benito \\ BI Norwegian School of Management \\ Nydalsveien 37 \\ N-0484 Oslo, Norway \\ gabriel.r.g.benito@bi.no
}

February 27, 2008

${ }^{*}$ Corresponding author 


\title{
MANAGING THE INTERNALISATION PROCESS \\ - A THEORETICAL PERSPECTIVE
}

\begin{abstract}
Internalisation theory informs us about why and when multinational enterprises (MNEs) internalise foreign operations, but has less to say about how the internalisation should be prepared and exercised when foreign market operations initially are carried out by local, outside agents. Drawing on insights from managerially-oriented literature, this paper explores the role of management in situations where the market transaction costs of using outside agents are negligible at market entry, but grow over time. A key question pertaining to this situation is: what management instruments may ensure persistent concurrence between changing pressure for internalisation in a foreign market and the effectuated internalisation of an MNE in that market? Management instruments and strategies that potentially support 'staged internalisation' include appropriation of the local outside agent's financial assets (including equity) as well as non-financial assets in relation to user rights, customer relations, and value added activities.
\end{abstract}

JEL CODES: F23, L22, M21

KEYWORDS : Internalization, multinational enterprises, management. 


\section{Introduction}

Internalisation theory has been has been one of the most important and influential theories within the field of international business (Buckley/Casson 1976, Hennart 1982, McManus 1972, Rugman 1981). It has been used to explain the circumstances under which a firm replaces imperfect (or non-existent) external markets by internal coordination (Buckley 1993). Together with market power explanations (Hymer 1960/1976, Yamin 1994) and knowledge-based explanations (Grant 1996, Kogut/Zander 1993), internalisation theory offers a paradigm able to explain - with a high degree of accuracy under certain assumed conditions - why multinational enterprises (MNEs) choose to exercise daily managerial control over foreign operations rather than work through other firms under contractual or other arrangements. Hence, on a general level internalisation theory can explain the existence of MNEs. By including time-responsive factors that pull in the direction of internalisation the theory can also predict patterns and directions of growth of MNEs. However, the theory excludes any meaningful role for management, particularly in the real world dynamic context of constantly evolving foreign market conditions and operations of a MNE (Buckley 1993).

Therefore, in this article we seek to develop internalisation theory by including managerial judgement considerations in the context of dynamic influences on the development of foreign operations. We introduce the managerial role by eliciting best management practices in situations where the market transaction costs of using outside agents (local operators) are negligible at market entry, but grow over time. A key question pertaining to this situation is: what management instruments may ensure persistent concurrence between a changing pressure for internalisation in a foreign market and the effectuated internalisation of an MNE in that market?

The article is organised as follows: in the next section (section 2) we discuss the roles of management that are currently provided for in internalisation theory and present a basic conceptual framework that includes changing internalisation pressures over time. In section 3 we examine various dynamic drivers of internalisation, which trigger either increasing costs of using an external organisation (i.e. increased market transaction costs) or decreasing costs of using an internal organisation (e.g. reduced penalty costs of underutilized production capacity). In section 4 we delineate the managerial scope of internalisation in terms of enabling gradual internalisation 
with a minimum of renegotiation costs. In section 5 we examine the various assets of an outside agent that may be subject to internalisation. Internalisation theory has primarily focused on appropriation of financial assets (including equity) with less attention to the various ways MNEs internalise non-financial assets of local operators. We conceptualise financial and non-financial assets by configuring the assets in relation to a value chain template. Furthermore we translate this configuration of financial and non-financial assets into a formal expression of the degree to which an MNE has internalised operations pertaining to a foreign market. Section 6 examines different modus operandi of 'staged internalisation' in relation to financial as well as nonfinancial assets. We exemplify how MNEs may put in place options for gradual internalisation in relation to the equity of the local operator, but also in relation to non-financial assets. The section includes a number of practical examples of how MNEs at the initial point of foreign market entry can put in place options for gradual internalisation in order to curb the renegotiation costs of multiple contract adjustments at later points in time. We conclude by discussing the possible extension of internalisation theory with the management of 'staged internalisation' (section 7) thereby drawing attention to the scope for further development of internalisation theory in a more managerial and dynamic direction.

\section{Developing internalisation theory}

Existing internalisation theory basically assigns three roles to MNE management, see Figure 1.

Figure 1: Management roles in existing internalisation theory

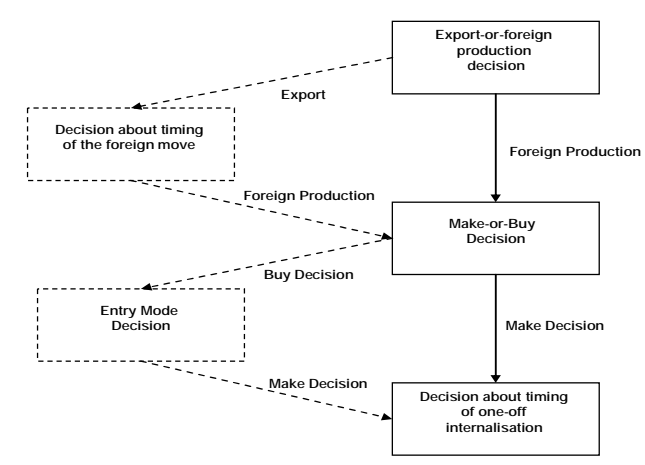


Firstly, managers need to decide whether the MNE should produce at home and export to the foreign market in question or produce in the foreign market (see e.g. Horst 1974). Secondly, the managers face a make-or-buy choice whenever localisation advantages favour production in the foreign market (Dunning 1980). Thirdly, managers have to decide the timing of internalisation (Buckley/Casson 1981) in cases where the 'buy' choice precedes internalisation'.

Seeing market exchange as the 'default option', internalisation theorists have first of all focused on the identification and analysis of various market imperfections that may result in internalisation. Since theorists have focused on a market efficiency rather than market power explanation (see e.g. Calvet, 1981), MNE managers have been assigned a 'neoclassical' role as omniscient administrators of market imperfections - and not creators of market imperfections ${ }^{2}$. In this perspective the managerial task in internalisation theory is first of all to observe the various - mostly exogenous - factors of choice relevance, and only to a limited extent to involve oneself in complex managerial discretion. Exact observation of internalisation-relevant factors (such as market size and degree of asset specificity) univocally directs the right choice. Furthermore, the choices are relatively simple ones: produce at home or in the foreign market; make-or-buy; when to internalise?

Our discussion of new and more profound management aspects in relation to internalisation theory takes as a departure point Buckley's (1993) article entitled 'the role of management in internalisation theory'. In that article Buckley concludes that, at the beginning of the 1990s, there was considerable room for developing internalisation theory in a more management-oriented direction. This was not to say that the role of management was ignored inasmuch as "strategic behaviour can be identified within the internalisation framework by firms securing exclusive access to key inputs and tieing in customers" (p. 206). In particular, Buckley stresses the need for theory development incorporating a more important role for management in the following two, closely interrelated issues:

1) The theory maintains a rather static view of internalisation - being considered a state rather than a process. Hence, "to incorporate a theory of management, it is essential to move away from a comparison of states to a comparison of processes... Progress can be made by comparisons of the changing balance of the boundary between 'firm' and 'market' and intermediate states over given time periods" (Buckley 1993, p. 201). 
2) There is an oversimplified choice for managers between markets and hierarchies. Hence, "the narrow view that managers simply make 'buy or build' decisions ... needs to be extended" (Buckley 1993, p. 206).

The two issues point in the same direction, namely that internalisation may be a long-term manageable process rather than a time-compressed, binary choice ${ }^{3}$. The contextual focus of this paper is those situations where non-hierarchical entry modes enjoy a temporal superiority over hierarchical modes (for reasons that will be elaborated on in the next section). As an example, licensing or joint ventures may be used before wholly-owned production subsidiaries, or independent distributors may precede sales subsidiaries.

Against this background we use the term, staged internalisation, for those cases where the transition from non-hierarchical to hierarchical foreign operation modes unfolds as a managed and stepwise process. We contend that the potential pay-off to MNEs of undertaking staged internalisation may be considerable: at any point in time an ideal outcome for the firm would be when the degree to which a firm has internalised its foreign activities is in perfect balance with the underlying drivers of internalisation. For example, a MNE typically uses many, different value added activities in a given foreign market. Some of the activities in this country may be characterised by a high degree of asset specificity whereas other activities have low specificity. Because of considerable scale and scope economies and local market knowledge enjoyed by a local, outside agent (e.g. a licensee of the MNE), the entrant MNE only internalises local activities for which a high degree of control is considered to be of utmost importance, such as R\&D (Buckley/Hashai 2005). Furthermore, the MNE internalises more and more value added activities in the foreign country as the degree of asset specificity of these activities grows, which typically occurs in small, consecutive steps (see argument below in coverage of dynamic drivers).

Figure 2 illustrates three scenarios that are different in terms of the fit between underlying internalisation drivers (indicated by the broken line), such as increasing asset specificity, and effectuated internalisation of operations in a given foreign market (indicated by the full line). It is assumed that the underlying pressure for internalisation (or, internalisation advantage) increases monotonically with elapsed time of operations in the foreign market. Thus, the $\mathrm{X}$-axis indicates elapsed time of operations in the market and the $\mathrm{Y}$-axis the degree to which the foreign market operations is internalised (measured as a continuum from 0-100 \%). 


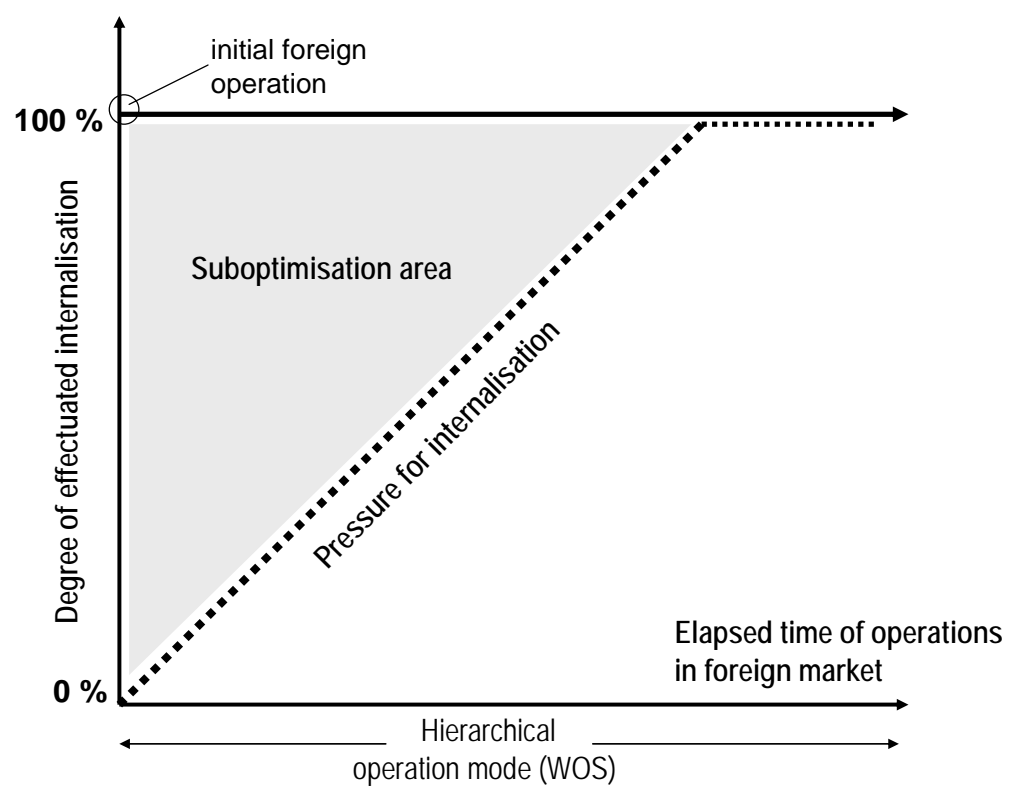

Figure 2a depicts a scenario of immediate internalisation that, for example, may be justified by excessively high anticipated/potential switching costs (Benito/Pedersen/Petersen 1999). Such a scenario is typically assumed in the entry mode literature, especially that based on transaction cost economics, as illustrated by the following statement in the much-cited study of foreign distribution by Anderson and Coughlan (1987, 71): "Channel choices, once made, are often difficult to change. Hence, the question of whether to integrate foreign distribution can have a large and lasting impact on the success of a firm's international operations."

The situation depicted in Figure $2 \mathrm{a}$ is one in which internalisation, although economically justified by potential switching costs, actually is 'premature' inasmuch as the hierarchical operation mode - the wholly-owned subsidiary (WOS) - in contrast to for example a local, independent licensee - operates below minimum efficient scale during the first years after market entry. Hence, the governance structure is sub-optimal in terms of production costs (although perhaps not with regard to transaction and switching costs). The sub-optimisation in terms of production costs (i.e. sacrificed scale economies) is indicated by the grey area. Figure $2 b$ illustrates a scenario with one shift of governance structure - from a contractual mode (e.g. licensing) to the hierarchical mode (WOS). The shift halves the sub-optimisation (grey) area. ${ }^{4}$ 
Figure 2b: Internalisation - one step

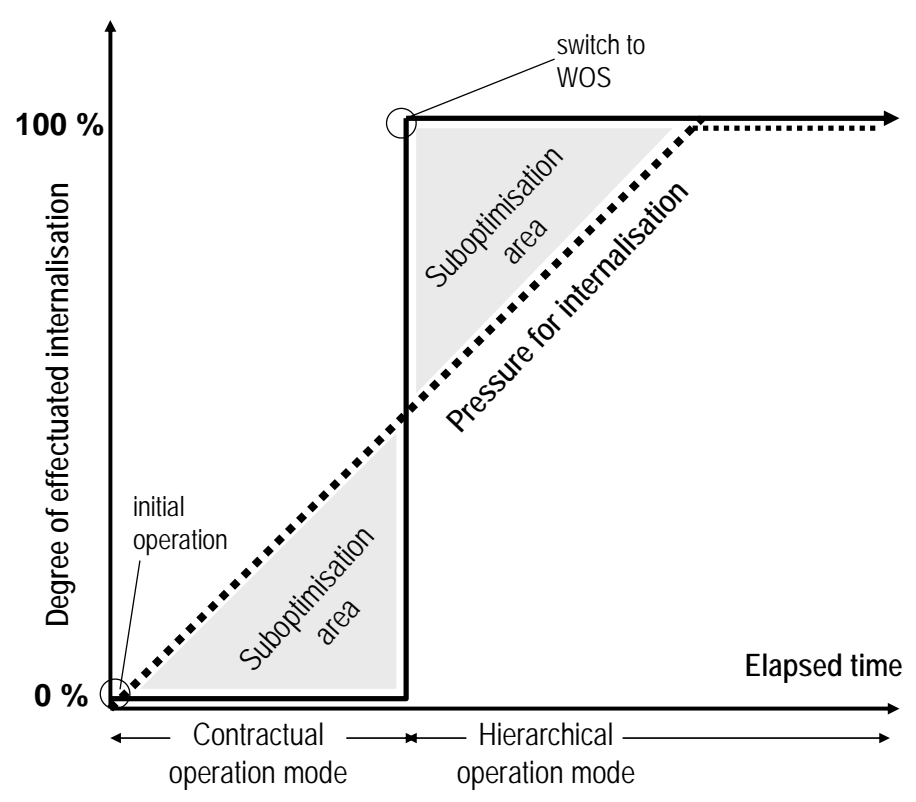

The sub-optimisation area is further reduced when the MNE makes two shifts of governance structures/operation modes (see Figure 2c). The first shift is from a contractual arrangement to a 50/50 equity joint venture, and later from a joint venture to a sole venture (WOS) - i.e. a hierarchical organisation.

Figure 2c: Internalisation - two steps

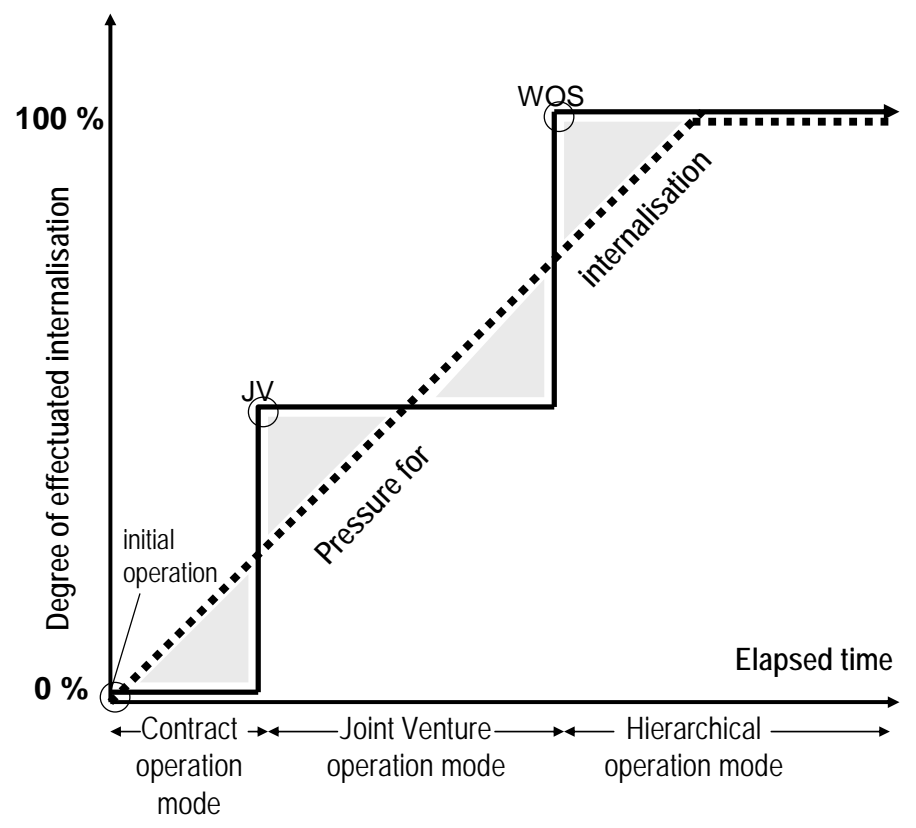


Altogether, the three scenarios show that the sub-optimisation area diminishes as the number of shifts - or internalisation steps - increases. Ideally, a perfect concurrence between the particular need for internalisation at a certain point in time - which would be determined by the underlying internalisation drivers - and the actual internalisation at that point in time would eliminate the sub-optimisation area completely. It is also clear that there is a trade-off between on the one side - production cost savings due to perfect concurrence obtained through frequent internalization steps, and - on the other side - the additional transaction costs in the form of renegotiation costs. A basic premise of our line of reasoning is that while achieving a perfect fit between the underlying internalisation drivers and the effectuated internalisation may have a high payoff, it also constitutes a major managerial challenge.

\section{Dynamic drivers of internalisation}

Why is it that a MNE should not always internalise its activities in a foreign country overnight? What are the drivers that over time gradually build pressure for internalisation as the activities in the foreign country unfold, and therefore suggest that effectuation of internalisation should be gradual as well? There are many dynamic drivers of internalisation (as well as drivers of externalisation, as pointed out in for example the franchising literature). The aim of this section is not to provide a comprehensive account of these drivers. Rather, we focus on four drivers, which are prominent in the business economics literature. The four drivers of internalisation covered in this section fall into two main groups: (i) those that increase the transaction costs of (external) markets and (ii) those that decrease the governance costs of internal organisation. ${ }^{5}$

The archetypal dynamic driver of market transaction costs is captured by Williamson's (1975) notion of 'fundamental transformation': the change from a large to a small numbers bargaining situation and eventually a bilateral monopoly - a lock-in situation. The increasing economic interdependency between the two parties - in casu an entrant MNE and a local operator - builds up a pressure for internalisation. The key issue is increasing asset specificity (Williamson, 1975, 1985): Mutual supplier-buyer adaptation implying non-negligible relationship-specific investments bring about a change from a large to a small numbers bargaining/exchange situation between the exchanging economic agents. The 'lock-in' situation leads to exceedingly costly haggling about the quasi-rents resulting from the mutual adaptation that, in turn, motivates a move away from an arm's length market structure to a hierarchical 
governance structure. Hence, Williamson describes a process - the fundamental transformation of increasing asset specificity eventually leading to internalisation, but the governance structure is either market or hierarchy ${ }^{6}$. In other words, the internalisation is presented as a one-off switch.

The dynamic drivers leading to decreasing governance costs of internal organization are of mainly three types: (a) increasing sales volume or market size; (b) diminishing market uncertainty through experiential learning, and (c) release of management resources. Usually, the three drivers cannot, by themselves, justify internalisation - they only bring down the cost of using hierarchical modes to an equivalent level of the costs of arm's length and contractual solutions. In other words, they do not really constitute 'pressure' for internalisation. Instead, they lower the threshold of internalisation should market imperfections arise, such as hold-up situations motivated by asset specificity (Williamson, 1983).

(a) Increasing sales volume or market size (Buckley/Casson 1981): Growing market size may constitute an internalisation driver inasmuch as contractual operation methods (e.g. licensing) in general are more economical at a small or medium local market size than are investment modes

Figure 3: Market growth as a driver of internalisation

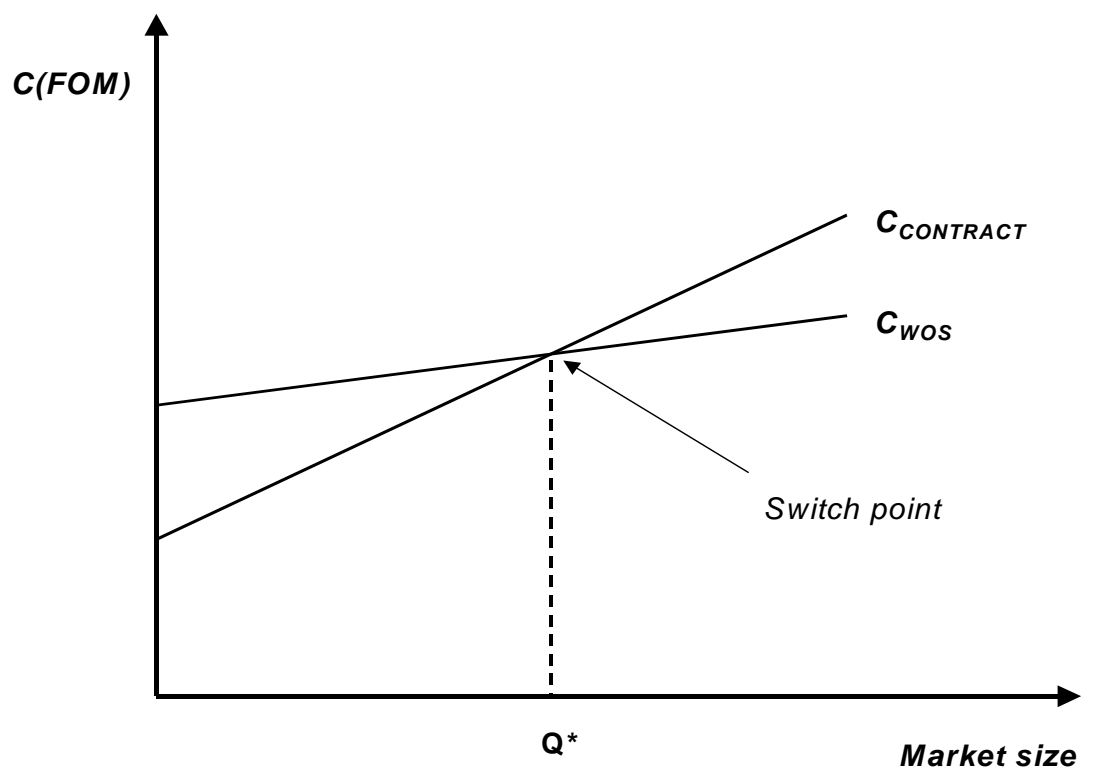


such as wholly owned subsidiaries (WOS). In Figure 3 the market size Q* indicates the 'switch point' where the costs of operating a contractual foreign operation mode $\left(C_{\text {contract }}\right)$ are equal to those of an investment mode $\left(C_{\text {WOS }}\right)$. In this presentation the entrant firm faces a make-or-buy choice: either contract or WOS (as we disregard the location choice between export and local production). Again, the internalisation is presented as a one-off phenomenon.

(b) Reduced market uncertainty through experiential learning (Johanson/Vahlne 1977): The entrant firm's acquisition of foreign market knowledge reduces perceived market risk and uncertainty which, in turn, prompts the entrant firm to internalise, e.g. switching from a sales agent to a sales subsidiary - see Figure 4. In Johanson and Vahlne's model, internalisation comes about as a result of a learning process. However, it is less clear to what extent the internalisation as such - the switch from a sales agent to a sales subsidiary - is a process as well. Johanson and Vahlne (1977) suggest a gradual increasing resource commitment to the foreign market, although the archival data of the four Swedish MNEs, from which Johanson and Wiedersheim-Paul (1975) derived an 'establishment chain', indicated a one-off switch - not a process. ${ }^{7}$

Figure 4: Experiential learning as a driver of internalisation

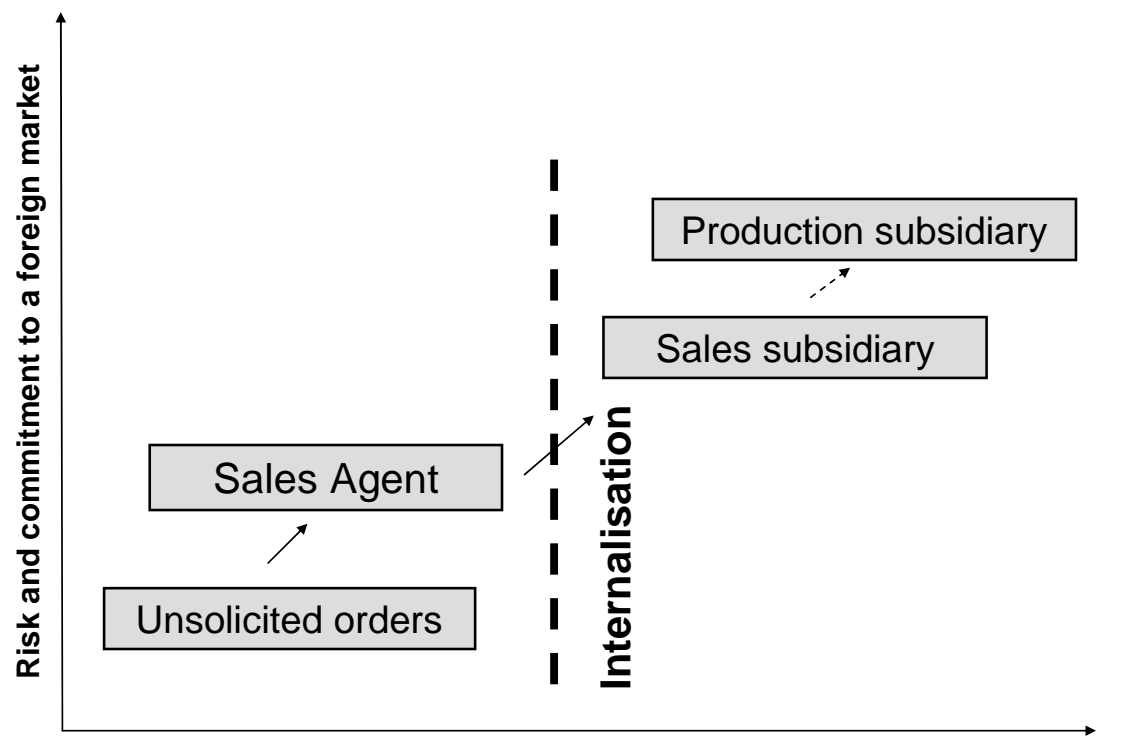

Experiential Learning/Elapsed time 
(c) Release of management resources (Penrose 1956, 1959): Penrose demonstrated how growing managerial scope economies release management resources that, in turn, can be employed in the establishment of foreign production subsidiaries (see Penrose 1956). In general, the growth of an entrant MNE may free financial funds and human resources that enable internalization, although the international management literature points to the many frictions that limit the exercise of such resources in an international context. Whereas the growth of the (entrant) firm is a process per se, it seems to be unresolved in the literature whether the internalisation that arises from the growth should be viewed as a one-off event or a process.

In sum, the extant business economics literature gives us a general picture of various underlying drivers or forces promoting internalisation, including increasing market size, experiential learning, firm growth, and increasing mutual interdependency (asset specificity). The internalisation as such, however, is either assumed to be in place from the outset (as a hierarchical entry mode), or exercised as a one-off switch from externalisation ('market') to internalisation ('hierarchy'). In the latter case, increasing pressure for internalisation of local market activities builds up and at a certain point in time the MNE exercises complete internalisation - as illustrated in Figure 2b.

Alternatively, one may envisage internalisation as a stepwise, even incremental process, where effectuated internalisation is synchronised with the underlying drivers of learning, growth, etc. In other words, the internalisation unfolds as the need grows. Rather than making a dichotomous make-or-buy choice, entrant MNEs combine make and buy modes until a 100\% internalisation eventually - if ever - is completed. By combining externalisation and internalisation in an optimal blend the entrant firm gets the best of both worlds. A practical example of this is found among international franchisers that, at any point in time, aim at managing an optimal mix of franchised and company-owned outlets. Of course, when studying the dynamics of international franchising, the internalisation case is frequently reversed with the franchisor undertaking gradual externalisation by diminishing the proportion of company-owned outlets (Fladmoe-Lindquist/Jacque 1995, Lafontaine/Kaufman 1992, Welch/Benito/Petersen 2007). Nevertheless, there are many cases of franchising companies following a pattern of taking over (i.e. internalising) previously franchised outlets - because of problems encountered in specific foreign markets or more generally with the franchise system, or due to changes in business strategy and the development of confidence in directly running outlets as experience and learning develop. Because of problems with some of its franchisees in the UK, the Tie Rack chain 
terminated these franchises and embarked on a policy of opening new outlets on a companyowned basis because of this experience (Gourlay 1994). It is noteworthy that McDonald's has maintained a strong company-owned outlets emphasis in the UK and Japan (via a JV) in contrast to its more general position of emphasising franchising (Welch/Benito/Petersen 2007).

In a scenario of incremental internalisation we implicitly assume away the occurrence of switching costs. However, without careful planning, stepwise internalisation is not feasible or excessively expensive. As a consequence, internalisation becomes the initial and permanent mode (see Figure 2a), or the internalisation takes place as a single one-off switch in order to reduce switching costs (see Figure 2b). However, real options and switching cost studies - see, for example, Kogut (1991) and Petersen, Welch and Welch (2000) - suggest that entrant firms might be able to reduce switching costs through careful planning and managerial discretion. The role of 'managerial discretion' in internalisation theory is discussed next.

\section{Delineating the managerial scope of internalisation}

The dynamic drivers of internalisation outlined in the previous section have in common that they tend to be less susceptible to managerial influence. Market growth is to a large extent determined by exogenous factors; release of management resources depends on the scope economies of the MNE as a whole; experiential learning is determined by the nature of activities undertaken and outcomes from them, and elapsed time, rather than by management, although management does have a role in the choice of activities to be undertaken; and asset specificity is mainly on the part of the local operator inasmuch as the investments of the MNE are country rather than relationship-specific. Since the dynamic drivers are underlying drivers largely beyond the scope of management, the benefits of gradual internalisation are more or less given seen through the lens of the MNE manager. Figure 5 depicts the marginal cost (MC) and benefit (MB) of the frequency of internalisation, i.e. the number of internalisation steps within a given time period in a given foreign market. The MB curve follows the same assumptions as in Figure 2a-c: since the pressure for internalisation increases proportionately with the elapsed time of operations in a given foreign market, the sub-optimization area divides into halves for every additional internalisation step. Hence:

$$
\mathrm{MB}=\varphi(1 / 2)^{\mathrm{S}-1} \text { where, }
$$

$\mathrm{MB}=$ marginal benefit of one additional internalisation step; 
$\varphi=$ cost reduction obtained by introducing a first, single internalisation step (see Figure $2 b$ );

$\mathrm{S}=$ number of internalisation steps within the observed time period.

Figure 5: Management scope of internalisation

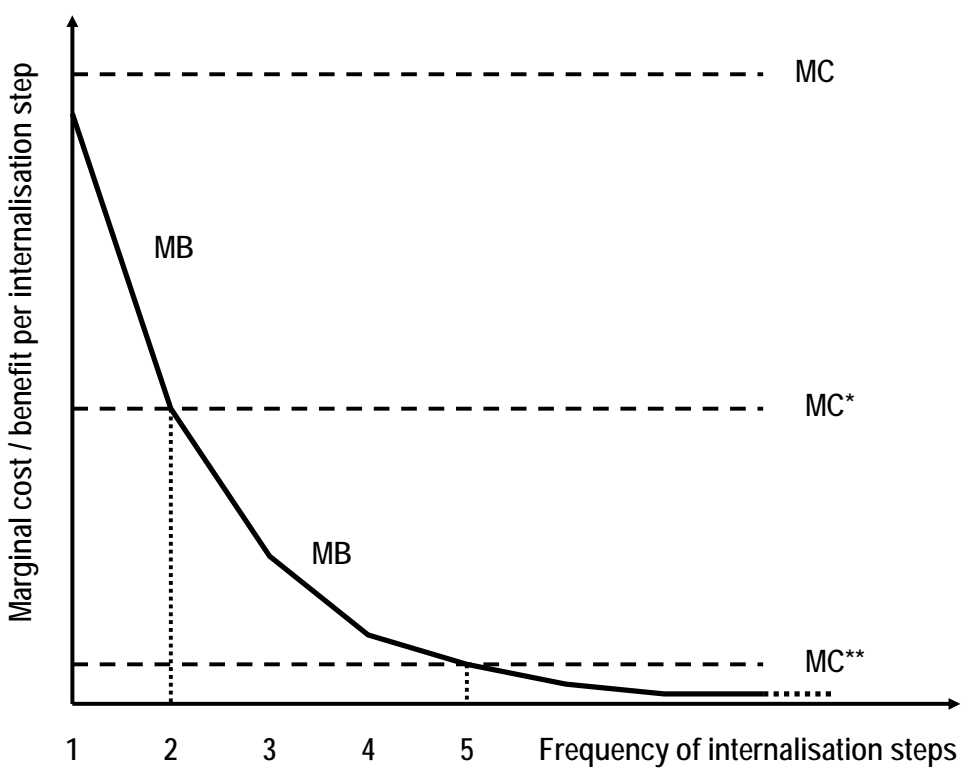

The MB curve has a strong downward slope and moves asymptotically towards zero (the X-axis). In this scenario, the benefit of more than five internalisation steps is diminutive. The marginal cost of internalisation (MC) is assumed constant ${ }^{8}$. However, the cost level across the internalisation steps is assumed to be strongly influenced by MNE managers. Managers' potential influence on MC levels is indicated by including three different horizontal cost lines in Figure 5: $\mathrm{MC}>\mathrm{MC}^{*}>\mathrm{MC}^{* *}$. The upper cost line, $\mathrm{MC}$, does not intersect with the $\mathrm{MB}$ curve at any point simply because the potential additional renegotiation cost exceeds the marginal benefit at any internalisation step - even the first, most beneficial. The MC* line intersects the MB curve at two internalisation steps. Hence, the MNE will be better off by making one additional internalisation step beyond its initial step and will neither be better or worse off by taking the extra internalisation step. The MB-MC** intersection is found at five internalisation steps. The level of renegotiation costs in the $\mathrm{MC}^{*}$ and $\mathrm{MC}^{* *}$ cases are significantly lower than in the $\mathrm{MC}$ case indicating that the MNE managers have been much more successful in putting in place options for gradual internalisation at market entry ${ }^{9}$, and these options effectively curb renegotiation costs later on. A prerequisite for the elucidation of options for gradual internalisation is the 
conceptualisation and operationalisation of 'staged internalisation' and a portrayal of different ways in which it might unfold. Hence, in the next section we develop a conceptual framework for analysing how 'staged internalisation' is practised by MNEs and how the degree of internalisation can be measured in formal terms.

\section{Conceptualisation and measurement of 'staged internalisation'}

In order to elucidate options for gradual internalisation we should clarify the various ways in which entrant firms, step by step, can take over the foreign market operations of a local outside agent. Until now, internalisation theorists have mainly associated internalisation processes with MNEs' appropriation of the financial assets - notably equity - of the local operator. However, internalisation processes may, just as well, take place through appropriation of specific, nonfinancial assets: tangible assets, such as specialised tools/machinery, as well as intangible assets, e.g. goodwill in relation to tieing in local key personnel, suppliers and customers. The processwise internalisation of (non-financial) assets may be described along three different value chain dimensions, see Figure 6.

Figure 6: Internalisation of foreign markets assets along three dimensions

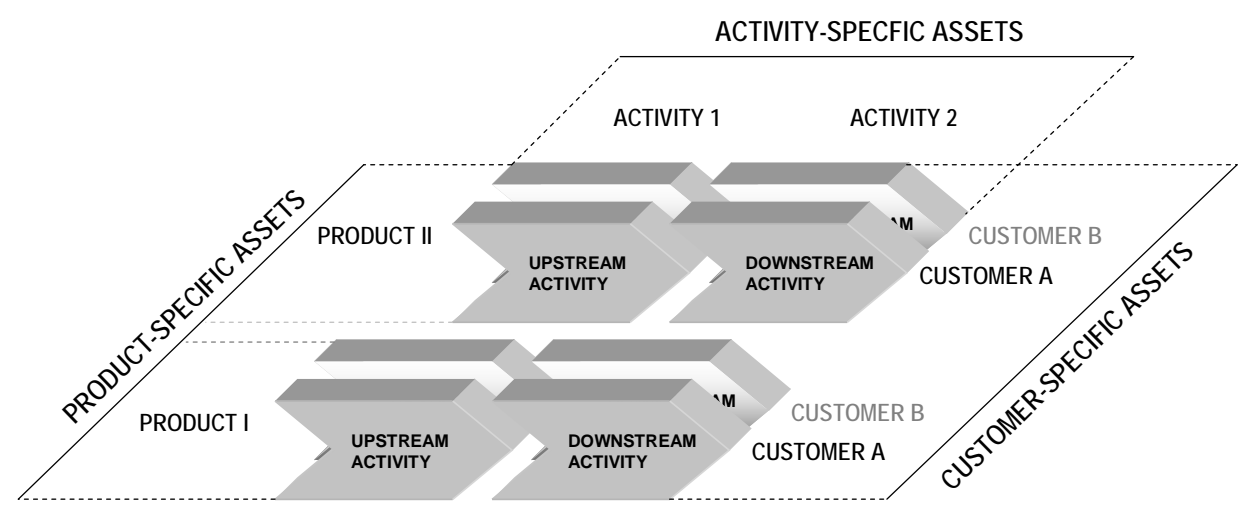


(a) Internalisation of product-specific assets: The first dimension of internalisation of nonfinancial assets (indicated by the left-hand axis in Figure 6) pertains to the multiplicity of value chains, or product families, that a local operator may operate on behalf of a MNE. Hence, an MNE may have licensed out several product or process technologies to one or more local operators. Each licence may constitute a separate value chain. Altogether, the value chains make up the 'value system' (Porter 1985) operated in the foreign market by a MNE single-handedly or in collaboration with local operators. As an example, until recently the Danish pharmaceutical MNE, Lundbeck A/S (producer of medicine for the treatment of diseases of the central nervous system) had two licence arrangements in the Chinese market which related to two different product families of medicine. Another example is the Indian operations of Norsk Hydro, a Norwegian MNE that was very diversified until quite recently. During the 1990s, the various divisions of Norsk Hydro had licensed out production technologies of different product families to local operators (Tomassen/Welch/Benito 1998). However, for reasons of simplification only two value chains (product families) are indicated in Figure 6; but of course, some MNEs may operate numerous value chains in a single foreign market - as in the Norsk Hydro example. An MNE can internalise foreign market activities by pulling back product licences one by one until it has resumed control of all its products produced and marketed in the foreign country. In this case the focal non-financial assets are the user rights (licences) held by the local operator. By the nonrenewal of its licences the MNE 'appropriates' these assets from the local operator and internalises the foreign market activities. Note that in this case no financial assets (equity) have been acquired by the entrant MNE.

(b) Internalisation of activity-specific assets: A second internalisation process dimension (indicated by the upper axis in Figure 6) pertains to assets of specific activities of the individual value chains operated by local, outside agents. In Figure 6 value adding activities are, again, simplified into only two activities: an upstream activity and a downstream activity (hence, we disregard the business reality that in most cases foreign market operations are composed of numerous discernible activities). As an example of internalisation of an upstream activity asset, a MNE may provide specialised machinery to a foreign contract manufacturer. Because the machinery can be used only in relation to manufacturing for the MNE (and not other customers) the contract manufacturer could tackle this asset specificity problem by leasing instead of buying 
the specialised machinery from the MNE. To illustrate internalisation of a downstream activity asset take the example of a MNE paying salaries to individuals in the local distributor's organisation on the condition that these individuals focus entirely on sales of the exporter's products. In this example the focal, non-financial and intangible asset is goodwill in the form of tieing in key sales and marketing personnel of the local, outside agent. By putting key personnel on its own payroll the MNE 'appropriates' goodwill assets of the local operator. Other examples of internalisation assets related to downstream activities comprise wholesale activities (Petersen/Welch 2000), marketing (Williamson 1992), and after-sales activities (Gabrielsson/Kirpalani/Luostarinen 2002).

(c) Internalisation of customer-specific assets: The third, and last, internalisation process dimension (indicated by the right-hand axis in Figure 6) is pertinent to assets of customer or supplier relationships. ${ }^{10} \mathrm{~A}$ MNE may gradually internalise the foreign market operations by converting local customers (or, groups of customers) to 'house accounts' one by one. Hence, the MNE 'appropriates' the outside agent's goodwill assets in the form of tieing in customers. The case of Guess! Italia S.r.l. is an illustration of this form of internalisation. Guess! Inc. is an US producer of higher-end, fashionable jeans and various accessories. The US company licensed the rights to market and sell its products in Europe to Guess! Italia S.r.l. After a management change in 2004 Guess Italia embarked on a policy of converting the larger and more important local customers (retailers) in European markets to 'house accounts' (Source: Personal communication with local distributors). International franchisors usually externalise activities by converting company-owned outlets to franchised outlets. But, as noted earlier, sometimes franchisors turn around the process and internalise outlets (and thereby 'appropriate' customer relationships within given sales districts). As an example, Yum Brands Inc. - the operator of KFC and Pizza Hut in China - during 2005 moved from franchised to company-owned outlets in certain Chinese sales districts as a reaction to various problems encountered with local franchisees (http://www.franchiseek.com/China/Franchise_China_News 0505.htm). ${ }^{11}$ In Figure 6 we have indicated a situation where only two customers (or, customer groups) are served in the foreign market.

As a general rule, internalisation of non-financial assets of local operators pertains to specific products (product families), value-adding activities, or customers (customer groups). In 
contrast, when MNEs acquire financial assets of local operators these assets are usually not related to any specific product, activity, or customer, but are pertinent to the value creation of the local operator as a whole. Hence, a $50 \%$ equity share of the local operator implies internalisation of $50 \%$ of all assets across products, activities, and customers. However, exceptions to this general rule may apply. In principle, a MNE may acquire financial assets (equity) of joint ventures that are established for a very specific purpose, such as the marketing and sales of a certain product, the conduct of certain activities (e.g. R\&D), or to focus on a certain customer segment. Keeping in mind this possibility of acquiring both financial and non-financial assets in relation to specific products/activities/customers we can express a MNE's degree of internalisation in relation to a given foreign market by the following equation:

$$
\mathrm{I}^{x}=\sum_{i=1}^{I} \sum_{j=1}^{J} \sum_{k=1}^{K} \mathrm{E}_{i j k}^{x}\left(n f A_{i j k}^{x}\right)
$$

where

$\mathrm{I}^{X}=$ Focal MNE's degree of internalisation (in country $x$ )

$i=$ specific product (family)

$j=$ specific value chain activity

$k=$ specific customer (group)

$\mathrm{E}=\mathrm{MNE}$ 's ownership share

$n f A=$ non-financial asset

In the (special) case of a 50/50\% equity joint venture with a local operator in country $x$, E would equal 0.5 for any non-financial asset $(n f A)$ in that country. In cases where no equity joint ventures are formed with the local operator, E may equal any value in the interval $\{0 ; 1\}(0 \leq \mathrm{E} \leq 1)$.

\section{Examples of options for gradual internalisation}

After having conceptualised and operationalised 'staged internalisation' we can now address the question of how, in practice, MNE managers can stage the internalisation process by putting in place options for gradual internalisation. As stressed in the previous section, managers' creation of options for gradual internalisation at local operators in foreign markets may pertain not only to acquisition of equity, but also to non-financial assets relating to products, value added activities, and customers. These non-financial asset categories are by no means definitive, but they do 
identify the business reality that firms may use a variety of creative ways of absorbing and controlling a foreign partner beyond equity arrangements. In this section we will briefly outline each of the four aspects (equity included) and provide some practical examples of how MNE managers may be able to put in place options for gradual internalisation.

\section{Options for gradual internalisation in relation to financial assets (equity)}

Internalisation of equity is well-described in the international joint venture literature, although the focus has mainly been on institutional factors as determinants of changing ownership structures (see e.g. Gomez-Casseres 1987, Hennart 1988). In a study of entry strategies in emerging markets, Meyer and Tran (2006) coin the term 'staged acquisition' (similar to the term 'dynamic market entry' used by Buckley, 2007) to describe stepwise acquisition of a foreign partner. This is illustrated by reference to the case of 'staged acquisitions' practised in Poland and Vietnam by the international brewer Carlsberg. In these two emerging markets Carlsberg increased, in several rounds, its holding of equity shares in the two local operators - which at the same time were a licensee and a joint venture partner of Carlsberg. What was initially a minority stake was eventually turned into a majority stake or full acquisition. The Norwegian company Nera, a producer of low and medium capacity microwave radio link systems, followed a similar pattern when it entered the Indian market (Welch/Benito/Petersen 2007). Nera initially opted for a joint venture arrangement with an Indian partner, established in 1992, in which Nera held a 30 per cent equity position. This was extended in 1994 to a 45 per cent holding. Today, its subsidiary in India is a 100 per cent owned daughter company.

Such gradual acquisitions may be implemented via ad-hoc purchases of equity shares or through planned buy-out options. For example, Wal-Mart bought a six per cent stake in the Japanese supermarket chain Seiyu in 2002, but part of the agreement was an option to raise that share to $66.7 \%$ by 2007 . It exercised part of that option just nine months later with an increase to $37 \%$ (Fackler/Zimmerman 2003). This was gradually increased to $53 \%$ by mid-2007. From the perspective of staged internalisation, such optional buy-out arrangements, negotiated and assented to from the outset, are of particular interest. The case of Nilfisk A/S (a Danish producer of industrial vacuum cleaners) is an illustration of the consequences of not having equity buy-out options in place at market entry. In Spain - one of its major markets - the company was only allowed to acquire a $10 \%$ equity share of the local distributor, Nilfisk Aspiradoras - a very successful family-owned company. As a consequence of a general policy of majority control of its 
international distribution network, Nilfisk insisted on increasing its equity share. However, the Spanish distributor took exception to this move and engaged in a bitter legal dispute with Nilfisk to prevent it occurring (Petersen/Welch/Welch 2000). Similarly, Buckley (2007, p. 122) has observed that "flexibility in altering ownership choice in China is limited because the switching costs are high." Rather than negotiate options at the outset, companies may create contractual handcuffs that remove equity adjustment possibilities for some period of time. For example, in a recent joint venture deal between the multinational brewers SAB Miller and Molson Coors, covering operations in the US and Puerto Rico, the agreement includes a clause preventing either party from seeking shares in the other company for a period of 10 years (press release, 9 October 2007).

\section{Options for gradual internalisation in relation to non-financial assets}

Over time, an entrant MNE tends to take control of (i.e. ownership of) more and more nonfinancial assets of its local operator in the foreign market even though a seemingly arm's length contractual mode may be used. The acquired assets will typically be characterised by a high degree of specificity. Our presentation of practical examples of options for gradual internalisation will follow the 3-dimensional categorisation of non-financial assets outlined in the previous section. Hence, we start with internalisation of product-specific assets and the possible options that an MNE may put in place in relation hitherto:

Internalisation of product-specific assets (user rights, licensees): The entrant MNE, after having operated in a country with different licensing or other contractual arrangements, might move to acquire - or rather, withdraw - the user rights originally handed over to, for example, the local licensee or franchisee. In the case where several user rights are licensed out, the entrant MNE may choose to negotiate with the licensees separately and pull them back one by one. As an example, the before-mentioned Danish pharmaceutical MNE, Lundbeck A/S (producer of medicine for the treatment of diseases of the central nervous system) chose not to renew some of its licensing contracts with its Chinese distributors in 2006 as part of a new market strategy of upgrading its own presence in a rapidly growing market (Source: Personal communication). Licensing can also play a seemingly contrary internalisation role in that it is sometimes used by companies to extend control in joint venture situations. A licensing agreement with a JV partner 
which covers aspects such as management and marketing can be a means of delivering greater control of the JV operation in general (Welch/Benito/Petersen 2007).

\section{Internalisation of activity-specific assets:}

As an example of internalisation of non-financial assets specific to upstream value chain activities, the entrant MNE might place specialized machinery or staff at the disposal of a local OEM supplier. This could be associated with a concern about keeping control of key intellectual capital, particularly technology. The Japanese company Kyocera goes to considerable lengths to protect key intellectual property when manufacturing in other countries, as described by their technology and strategy manager: "Workers in its overseas plants are told precisely how to mix materials from Japan with local ones, but are given no idea what the ingredients are. When a part breaks on an advanced machine overseas, Kyocera's Japanese engineers disassemble and repair it in privacy, so that none of the local workers can take a good look" (Economist 2004, p. 67). Similarly, in outsourcing situations, in order to assure quality and delivery timeliness, many companies extend their involvement in their contractees' operations beyond arm's length purchases. For example, "Nike expatriates become permanent personnel in each factory producing Nike footwear, functioning as liaisons with corporate $R \& D$, headquarters, and worldwide quality assurance and product development efforts", so that contractees are more tightly locked into Nike's network and operations (Quinn/Hilmer 1994, p. 51). Such tie-ins can be a stepping-stone to equity arrangements (Welch/Benito/Petersen 2007).

As an example of internalisation of human assets specific to downstream activities, Petersen (1996) reports on Danish exporting firms that were paying salaries to individuals in the local distributor's organisation on the condition that these individuals focus entirely on sales of the exporter's products. An exporting firm reported that in order to 'persuade' the local distributor to allow this kind of 'headhunting' it had to pay considerable overheads - $30 \%$ of the wage paid to the specialized product manager was extended to the local distributor. Hence, an initial negotiation of payment of overheads to the local operator in order to achieve acceptance of this human asset internalisation would qualify as an internalisation option. More generally, it is clear that some companies are able to use such staffing arrangements as part of a stepping-stone to eventual takeover of the foreign distributor's operation (Petersen/Welch/Welch 2000). Integration of assets of specific value added activities is based on a division of responsibilities between the entrant MNE and the local operator (Buckley/Hashai 2004,2005, 
Gabrielsson/Kirpalani/Luostarinen 2002, Petersen/Welch 2002). Effectively, this is a case of mode combination (Welch/Benito/Petersen 2007). The entrant MNE takes over more and more value chain activities in the local market. As an example, the entrant firm only performs upstream activities initially, but over a period of time the local distributor hands over downstream activities to the entrant firm (Williamson 1992). During the 1990s the Danish MNE, Coloplast A/S (a producer of wound-care and incontinence products for hospitals), practised such a policy (Source: Personal communication). The policy was formulated as a three-step process where, first, the activities most closely related to end-customers (e.g. marketing) were internalised, then the ordinary sales activities, and lastly physical distribution, including warehousing and transportation.

Internalisation of customer-specific assets: Here, the entrant MNE is tieing in more and more customers in the foreign market by converting them to 'house accounts' (Coughlan/Anderson/Stern/El-Ansary 2006). In this way local distributors are gradually phased out of the market. Dutta, Bergen, Heide and John (1995) explain this dual distribution phenomenon by the principal's quest for better evaluation of local agents and by the principal's desire for posing credible threats of termination. From a staged internalisation perspective, the termination of local distributors is not kept as a threat, but is actually carried out over a period of time. The above-mentioned case of Guess! Italia S.r.l. (licensed producer of higher-end, fashionable jeans and various accessories) is an illustration of this approach. As mentioned earlier, in 2004 the Italian management group embarked on a policy of converting the larger and more important local customers (retailers) to 'house accounts'. The local distributors were compensated by a $7 \%$ commission on sales at the wholesale level on these 'house accounts' (Source: Personal communication with local distributors). In some of its larger national markets, such as Spain and France, the intention was clearly to internalise the entire business. Although Guess! Italia did not formulate its 'house account' policy at the time of the initial market entry, the offered 'house account' commission contributed to the creation of a type of internalisation option. A clearer option would, for example, be an initial agreement in which it is stipulated that all local customers engaging in cross-national activities are to be converted at some future point to 'house accounts' against suitable compensation. However, in many cases options for gradual internalisation are emergent - growing out of the development of the relationship between the parties, and related market knowledge improvement (Petersen/Welch/Welch 2000). 


\section{Conclusion}

In this paper we have applied a process view to the internalisation actions of MNEs and explored management issues in relation to this process. The suggested new management role in internalisation theory - managing a process, in part through the creation of options for gradual internalisation - is less susceptible to simple rules or choices and therefore lessens the deterministic flaw in existing internalisation theory. As has been demonstrated, a MNE may internalise a local operator in various ways - not only through acquisition of financial assets (equity), but also via 'appropriation' of non-financial assets specific to products, activities and customers. The idea of creating options for gradual internalisation is by no means new but the variety of areas in which these options can be put in place is hardly recognised in the IB literature (see Rugman/Li 2005 for an overview of the real option concept applied to international investments). Real options are not only of relevance to internalisation of equity, but also to internalisation of non-financial assets of the local operator. Further contributing to the managerial challenge of creating options for gradual internalisation is the wide range of ways in which these

Figure 7: 'New' management roles in internalisation theory

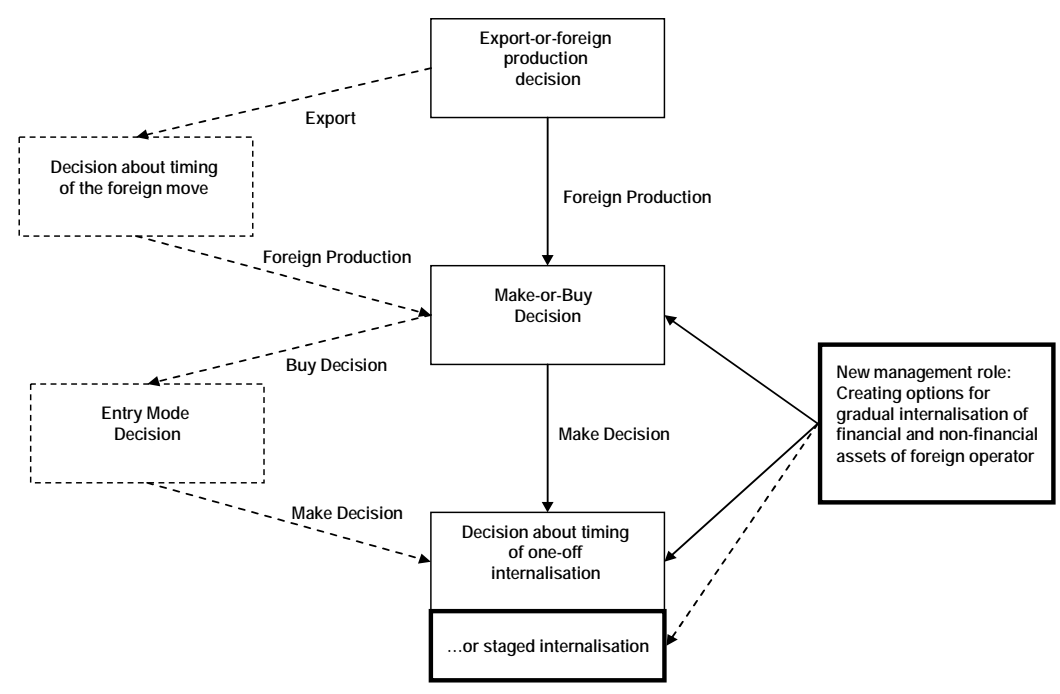


options can be designed. ${ }^{12}$ The new management role in internalisation theory of creating options for gradual internalisation is indicated by the box in the right-hand side of Figure 7 (see also Figure 1). As emphasised earlier, the creation of options potentially has a huge impact on the make-or-buy choice as well as the timing of internalisation inasmuch as these - until now relatively simple managerial choices suddenly become much more open-ended and consequently highlight the decision-making skills of MNE managers.

Hence, taking Buckley's (1993) discussion of the role of management in internalisation theory as our point of departure, we conclude that - fifteen years later - there is still considerable scope for developing the theory in a more managerial and practice-oriented direction. Our attempt at developing the theory of internalisation has focused on how the internalisation could be prepared and exercised when local outside agents in the foreign market (intermediaries, licensees, franchisees and the like) are used as temporary entry modes. Building on insights from recent international business literature as well as from marketing and management literature, we have provided examples of how management can play an active and substantive role in situations where the market transaction costs of using outside agents are negligible at market entry, but grow over time. The creation of options for gradual internalisation is a key aspect of attaining perfect concurrence between changing internalisation advantages and the operation methods used in a foreign market. Options for gradual internalisation pertain not only to 'staged acquisition' (Meyer and Tran, 2006), but also to the appropriation of non-financial assets of the independent local operator.

Our investigation of the conceptual issues surrounding internalisation in a more dynamic context, with a more invasive role for managers, demonstrates the scope for development in this direction. Inevitably, there is much to be accomplished in further conceptual clarification and extension of the ideas presented in this article. In addition, the many empirical illustrations used point to the need for more focused empirical studies that explore and extend the empirical foundation for concepts such as staged internalisation and the creation of options for gradual internalisation. 


\section{Endnotes}

${ }^{1}$ As indicated in Figure 6 internalisation theory may include two more management roles although one may consider these to be at the periphery of the theory, namely (a) the timing of initial export replacement with local production ('offshoring'), and (b) the specific choice of mode of operation in the case of a 'buy' decision (Contractor 1990, Datta/Herrmann/Rasheed 2002).

${ }^{2}$ In some models based on internalisation theory, MNE managers are assumed 'bounded' and not fully rational (see e.g. Buckley/Casson/Gulamhussen 2001).

${ }^{3}$ Of course, in those situations where no markets - not even contractual ones - exist, internalisation from the outset is the sole foreign entry mode, and it is meaningless to talk about internalisation processes (other than post-internalisation processes - such as post-acquisition integration processes). Most often, however, non-hierarchical entries (i.e. arm's length, contractual modes, and shared ownership operations in foreign markets) are feasible alternatives to establishing wholly-owned subsidiaries.

${ }^{4}$ This can be viewed as somewhat simplistic as it is clear that many companies using, for example, licensing employ a range of techniques within licensing arrangements to ensure that a degree of control or internalisation of the licensee is generated (Welch/Benito/Petersen 2007).

${ }^{5}$ Many of the issues raised are approached from a different perspective in, for example, the literature on international marketing and distribution, in dealing with aspects such as trust and interpersonal relationships between foreign intermediaries and exporters (Nes/Solberg/Silkoset 2007).

${ }^{6}$ However, later on Williamson (1991) included contractual governance structures as "hybrid forms", thereby leaving a strict market-hierarchy framework.

7 Petersen, Welch, and Nielsen (2001) discuss this discrepancy between the theoretical and empirical/operational level of Johanson and Vahlne's model and outline how an incremental learning process in fact may be echoed in an incremental internalisation process. Also, as firms increase their knowledge about internationalisation in general and their understanding of specific foreign markets in particular, they will tend to focus more on the - and thereby uncover unsatisfactory instances of - market 
performance of their outside agents. As a result, the perceived relative costs and benefits of internal versus external coordination shift in favour of internalised solutions.

${ }^{8}$ This simplified assumption reflects two opposite theoretical arguments: MC should decrease as a result of experience curve effects (Henderson/BCG, 1974). Conversely, MC should increase as a consequence of still higher asset specificity and, in turn, more and more costly haggling about the (growing) quasi-rents (Williamson, 1985). It is an unresolved empirical question as to whether the net effect is positive or negative.

${ }^{9} \mathrm{MC}$ includes the pre-entry cost of negotiating options for gradual internalisation. Potentially, contingent claim contracts may infer prohibitively high ink costs (Williamson, 1978; Hart, 1988). Hence, as a precondition for low MC, MNE management should be able to negotiate effective options for gradual internalization with a local operator at relatively low costs. See also section 6 for examples of relatively simple options for gradual internalisation.

${ }^{10}$ For reasons of simplification our argumentation will revolve around market seeking, rather than resource- or efficiency-seeking MNEs (Dunning 1993). Therefore, we focus on customer relationships only, but similar arguments apply to supplier-relationships of resource-seeking MNEs.

${ }^{11}$ In China less than $5 \%$ of all KFC outlets were franchised in 2005 ostensibly due to inadequate franchise regulations and enforcement of existing regulations.

${ }^{12}$ An obvious source of inspiration for the design of options for gradual internalisation is Williamson's discussion of various hold-up safeguards (Williamson, 1985). 


\section{References}

Anderson, E./Coughlan, A., International Market Entry and Expansion via Independent or Integrated Channels of Distribution, Journal of Marketing, 51, 1, 1987, pp. 71-82

Benito, G.R.G./Pedersen, T./Petersen, B., Foreign Operation Methods and Switching Costs:

Conceptual Issues and Possible Effects, Scandinavian Journal of Management, 15, 2, 1999, pp. 13-229.

Benito, G.R.G./Welch, L.S., Foreign Market Servicing: Beyond Choice of Entry Mode, Journal of International Marketing, 2, 2, 1994, pp. 7-27.

Buckley, P.J., The Role of Management in Internalisation Theory, Management International Review, 33, 3, 1993, pp. 197-207.

Buckley, P.J., The Strategy of Multinational Enterprises in the Light of the Rise of China, Scandinavian Journal of Management, 23, 2, 2007, pp. 107-126.

Buckley, P.J./Casson, M.C., The Future of the Multinational Enterprise, London: Macmillan 1976.

Buckley, P.J./Casson, M.C., The Optimal Timing of a Foreign Direct Investment, Economic Journal, 91, 361, 1981, pp. 75-87.

Buckley, P.J./Casson, M.C., Analysing Foreign Market Entry Strategies: Extending the Internalisation Approach, Journal of International Business Studies, 29, 3, 1998, pp. 539-561.

Buckley, P.J./Casson, M.C./Gulamhussen, M.A., Internationalization - Real Options, Knowledge

Management and the Uppsala Approach, Social Science, 1, 2001, pp. 229-261.

Buckley, P.J./Hashai, N., A Global System View of Firm Boundaries, Journal of International Business Studies, 35, 1, 2004, pp. 33-45.

Buckley, P.J./Hashai, N., Firm Configuration and Internationalisation: A Model, International Business Review, 14, 6, 2005, pp. 655-675.

Calvet, A.L., A Synthesis of Foreign Direct Investment Theories and Theories of the Multinational Firm. Journal of International Business Studies, 12, 1, 1981, pp. 43-59.

Contractor, F.J., Contractual and Cooperative Forms of International Business:

Towards a Unified Theory of modal Choice, Management International Review, 30, 1, 1990, pp. 31-54. 
Coughlan, A.T./Anderson, E./Stern, L.W./El-Ansary, A.I., Marketing Channels, (7th ed.), Upper Saddle River, N.J: Pearson/Prentice Hall 2006.

Datta, D. K./Herrmann, P./Rasheed, A. A., Choice of Foreign Market Entry Modes: Critical Review and Future Directions, Advances in International Management, 14, 2002, pp. 85-153.

Dunning J., Towards an Eclectic Theory of International Production, Journal of International Business Studies, 11, 1, 1980, pp. 9-31.

Dutta, S./Bergen, M./Heide, J.B./John, G., Understanding Dual Distribution: The Case of Reps and House Accounts, Journal of Law, Economics \& Organization, 11, 1, 1995, pp. 189-204.

Economist, 'Protecting the family jewels', June 26, 2004, p. 67.

Fackler, M./Zimmerman, A., Store Wars: Wal-Mart Takes on Japan, Far Eastern Economic Review, September 25, 2003, pp. 38-41.

Fladmoe-Lindquist, K./Jacque, L.L., Control Modes in International Service Operations: The Propensity to Franchise, Management Science, 41, 7, 1995, pp. 1238-1249.

Gabrielsson, M./Kirpalani, V.H.M./Luostarinen, R.K., Multiple Channel Strategies in the European Personal Computer Industry, Journal of International Marketing, 10, 3, 2002, pp. 73-95.

Gomes-Casseres, B. (1987). Joint Venture Instability: Is It a Problem? Columbia Journal of World Business, 12, 2, 1987, pp. 97-102.

Gourlay, R., Bring On the Clones - How Franchising Can Help Companies Grow', Financial Times, April 12, 1994, p. 13.

Grant, R.M., Toward a Knowledge-based Theory of the Firm, Strategic Management Journal, 17, special issue, winter, 1996, pp. 109-122.

Hart, O., Incomplete Contracts and the Theory of the Firm, Journal of Law, Economics and Organization, 4, 1, 1988, pp. 119-139.

Henderson, B., The Experience Curve Reviewed: V. Price Stability, Perpectives, Boston Consulting Group 1974.

Hennart, J.-F., A Theory of Multinational Enterprise, Ann Arbor, MI: The University of Michigan Press 1982.

Hennart, J.-F., A Transaction Cost Theory of Equity Joint Ventures, Strategic Management Journal, 9, 4, 1988, pp. 361-374. 
Horst, T., The Theory of the Firm, in Dunning, J. (ed.), Economic Analysis and the Multinational Enterprise, London: George Allen \& Unwin 1974, pp. 31-46.

Hymer S.H., The International Operations of National Firms: A Study of Foreign Direct Investment, Doctoral dissertation, Cambridge, MA: The MIT Press 1960.

Johanson J./Wiedersheim-Paul, F., The Internationalization of the Firm - Four Swedish Cases, Journal of Management Studies, 12, 3, 1975, pp. 305-322.

Johanson J./Vahlne J-E., The Internationalization Process of the Firm: A Model of Knowledge Development and Increasing Foreign Market Commitments, Journal of International Business Studies, 8, 1, 1977, pp. 23-32.

Kogut, B., Joint Ventures and the Option to Expand and Acquire, Management Science, 37, 1, 1991, pp.19-33.

Kogut, B./Zander, U., Knowledge of the Firm and the Evolutionary Theory of the Multinational Corporation, Journal of International Business Studies, 24, 4, 1993, pp. 625-645.

Lafontaine, F./Kaufman, P.J., The Evolution of Ownership Patterns in Franchise Systems, Journal of Retailing, 70, 2, 1994, pp. 97-113.

McManus, J., The Theory of the International Firm, in Paquet, G. (ed.), The Multinational Firm and the Nation State, Toronto: Collier MacMillan 1972, pp. 66-93.

Meyer, K./Tran, Y.T.T., Market Penetration and Acquisition Strategies for Emerging Economies, Long Range Planning, 39, 2, 2006, pp. 177-197.

Nes, E.B./Solberg, C.A./Silkoset, R., The Impact of National Culture and Communication on Exporter-Distributor Relations and on Export Performance, International Business Review, 16, 4, 2007, pp. 405-424.

Penrose, E.T., Foreign Investment and the Growth of the Firm, Economic Journal, 66, 262, 1956, pp. 220-235.

Penrose, E.T., The Theory of the Growth of the Firm, New York: John Wiley 1959.

Petersen, B., Explaining Cost-effective Export Market Penetration via Foreign Intermediaries with Special Emphasis on the Hold-Up Problem, Copenhagen Business School, Samfundslitteratur, Ph.D. series 4-96, 1996.

Petersen, B./Welch, D.E./Welch, L. S., Creating Meaningful Switching Options in International Operations, Long Range Planning, 33, 5, 2000, pp. 690-707.

Petersen, B./Welch, L.S./Nielsen, K.V., Resource Commitment to Foreign Markets: The 
Establishment Patterns of Danish Firms in South East Asian Markets, in Gray, S.J./McGaughey, S.L./Purcell, W.R. (eds.), Asia-Pacific Issues in International Business, Cheltenham, UK: Edward Elgar 2001, pp. 7-27.

Petersen, B./Welch, L.S., Foreign Operation Mode Combinations and Internationalization, Journal of Business Research, 55, 2, 2002, pp. 157-162.

Quinn, J.B./Hilmer, F.G., Strategic Outsourcing, Sloan Management Review, 35, 4, 1994, pp. 4355.

Rugman, A.M., Inside the Multinationals: The Economics of Internal Markets, New York: Columbia University Press 1981.

Rugman, A.M./Li, J., Real Options and International Investments, Cheltenham, UK: Edward Elgar 2005.

Tomassen, S./Welch, L.S./Benito, G.R.G., Norwegian Firms in India: Operation Mode Choice, Asian Journal of Business and Information Systems, 3, 1, 1998, pp. 1-20.

Welch, L.S./Benito, G.R.G./Petersen, B., Foreign Operation Methods: Theory, Analysis, Strategy, Cheltenham, UK: Edward Elgar 2007.

Williamson, O.E., Markets and Hierarchies. Analysis and Antitrust Implications, New York: Free Press 1975.

Williamson, O.E., Transaction-Cost Economics: The Governance of Contractual Relations, Journal of Law and Economics, 22, 2, 1978, pp. 233-267.

Williamson, O.E., The Economic Institutions of Capitalism, New York: The Free Press 1985.

Williamson, O.E., Comparative Economic Organization: The Analysis of Discrete Structural Alternatives, Administrative Science Quarterly, 36, 2, 1991, pp. 269-296.

Williamson, P.J., Europe's Single Market: The Toughest Test Yet for Sales and Distribution, Multinational Business (Summer), 1992, pp. 57-72. 


\section{SMG - Working Papers \\ www.cbs.dk/smg \\ 2003}

2003-1: Nicolai J. Foss, Kenneth Husted, Snejina Michailova, and Torben Pedersen: Governing Knowledge Processes: Theoretical Foundations and Research Opportunities.

2003-2: Yves Doz, Nicolai J. Foss, Stefanie Lenway, Marjorie Lyles, Silvia Massini, Thomas P. Murtha and Torben Pedersen: Future Frontiers in International Management Research: Innovation, Knowledge Creation, and Change in Multinational Companies.

2003-3: Snejina Michailova and Kate Hutchings: The Impact of In-Groups and OutGroups on Knowledge Sharing in Russia and China CKG Working Paper.

2003-4: Nicolai J. Foss and Torben Pedersen : The MNC as a Knowledge Structure: The Roles of Knowledge Sources and Organizational Instruments in MNC Knowledge Management CKG Working Paper.

2003-5: Kirsten Foss, Nicolai J. Foss and Xosé H. Vázquez-Vicente: “Tying the Manager's Hands": How Firms Can Make Credible Commitments That Make Opportunistic Managerial Intervention Less Likely CKG Working Paper.

2003-6: Marjorie Lyles, Torben Pedersen and Bent Petersen: Knowledge Gaps: The Case of Knowledge about Foreign Entry.

2003-7: Kirsten Foss and Nicolai J. Foss: The Limits to Designed Orders: Authority under "Distributed Knowledge" CKG Working Paper.

2003-8: Jens Gammelgaard and Torben Pedersen: Internal versus External Knowledge Sourcing of Subsidiaries - An Organizational Trade-Off.

2003-9: Kate Hutchings and Snejina Michailova: Facilitating Knowledge Sharing in Russian and Chinese Subsidiaries: The Importance of Groups and Personal Networks Accepted for publication in Journal of Knowledge Management.

2003-10: Volker Mahnke, Torben Pedersen and Markus Verzin: The Impact of Knowledge Management on MNC Subsidiary Performance: the Role of Absorptive Capacity CKG Working Paper.

2003-11: Tomas Hellström and Kenneth Husted: Mapping Knowledge and Intellectual Capital in Academic Environments: A Focus Group Study Accepted for publication in Journal of Intellectual Capital CKG Working Paper.

2003-12: Nicolai J Foss: Cognition and Motivation in the Theory of the Firm: Interaction or "Never the Twain Shall Meet"? Accepted for publication in Journal des Economistes et des Etudes Humaines CKG Working Paper.

2003-13: Dana Minbaeva and Snejina Michailova: Knowledge Transfer and Expatriation Practices in MNCs: The Role of Disseminative Capacity.

2003-14: Christian Vintergaard and Kenneth Husted: Enhancing Selective Capacity Through Venture Bases. 


\section{4}

2004-1: Nicolai J. Foss: Knowledge and Organization in the Theory of the Multinational Corporation: Some Foundational Issues

2004-2: Dana B. Minbaeva: HRM Practices and MNC Knowledge Transfer

2004-3: Bo Bernhard Nielsen and Snejina Michailova: Toward a Phase-Model of Global Knowledge Management Systems in Multinational Corporations

2004-4: Kirsten Foss \& Nicolai J Foss: The Next Step in the Evolution of the RBV: Integration with Transaction Cost Economics

2004-5: Teppo Felin \& Nicolai J. Foss: Methodological Individualism and the Organizational Capabilities Approach

2004-6: Jens Gammelgaard, Kenneth Husted, Snejina Michailova: Knowledge-sharing Behavior and Post-acquisition Integration Failure

2004-7: Jens Gammelgaard: Multinational Exploration of Acquired R\&D Activities

2004-8: Christoph Dörrenbächer \& Jens Gammelgaard: Subsidiary Upgrading? Strategic Inertia in the Development of German-owned Subsidiaries in Hungary

2004-9: Kirsten Foss \& Nicolai J. Foss: Resources and Transaction Costs: How the Economics of Property Rights Furthers the Resource-based View

2004-10: Jens Gammelgaard \& Thomas Ritter: The Knowledge Retrieval Matrix: Codification and Personification as Separate Strategies

2004-11: Nicolai J. Foss \& Peter G. Klein: Entrepreneurship and the Economic Theory of the Firm: Any Gains from Trade?

2004-12: Akshey Gupta \& Snejina Michailova: Knowledge Sharing in Knowledge-Intensive Firms: Opportunities and Limitations of Knowledge Codification

2004-13: Snejina Michailova \& Kate Hutchings: Knowledge Sharing and National Culture: A Comparison Between China and Russia

\section{5}

2005-1: Keld Laursen \& Ammon Salter: My Precious - The Role of Appropriability Strategies in Shaping Innovative Performance

2005-2: Nicolai J. Foss \& Peter G. Klein: The Theory of the Firm and Its Critics: A Stocktaking and Assessment

2005-3: Lars Bo Jeppesen \& Lars Frederiksen: Why Firm-Established User Communities Work for Innovation: The Personal Attributes of Innovative Users in the Case of Computer-Controlled Music

2005-4: Dana B. Minbaeva: Negative Impact of HRM Complementarity on Knowledge Transfer in MNCs

2005-5: Kirsten Foss, Nicolai J. Foss, Peter G. Klein \& Sandra K. Klein: Austrian Capital 
Theory and the Link Between Entrepreneurship and the Theory of the Firm

2005-1: Nicolai J. Foss: The Knowledge Governance Approach

2005-2: Torben J. Andersen: Capital Structure, Environmental Dynamism, Innovation Strategy, and Strategic Risk Management

2005-3: Torben J. Andersen: A Strategic Risk Management Framework for Multinational Enterprise

2005-4: Peter Holdt Christensen: Facilitating Knowledge Sharing: A Conceptual Framework

2005-5 Kirsten Foss \& Nicolai J. Foss: Hands Off! How Organizational Design Can Make Delegation Credible

2005-6 Marjorie A. Lyles, Torben Pedersen \& Bent Petersen: Closing the Knowledge Gap in Foreign Markets - A Learning Perspective

2005-7 Christian Geisler Asmussen, Torben Pedersen \& Bent Petersen: How do we Capture "Global Specialization" when Measuring Firms' Degree of internationalization?

2005-8 Kirsten Foss \& Nicolai J. Foss: Simon on Problem-Solving: Implications for New Organizational Forms

2005-9 Birgitte Grøgaard, Carmine Gioia \& Gabriel R.G. Benito: An Empirical Investigation of the Role of Industry Factors in the Internationalization Patterns of Firms

2005-10 Torben J. Andersen: The Performance and Risk Management Implications of Multinationality: An Industry Perspective

2005-11 Nicolai J. Foss: The Scientific Progress in Strategic Management: The case of the Resource-based view

2005-12 Koen H. Heimeriks: Alliance Capability as a Mediator Between Experience and Alliance Performance: An Empirical Investigation Into the Alliance Capability Development Process

2005-13 Koen H. Heimeriks, Geert Duysters \& Wim Vanhaverbeke: Developing Alliance Capabilities: An Empirical Study

2005-14 JC Spender: Management, Rational or Creative? A Knowledge-Based Discussion

\section{6}

2006-1: Nicolai J. Foss \& Peter G. Klein: The Emergence of the Modern Theory of the Firm

2006-2: Teppo Felin \& Nicolai J. Foss: Individuals and Organizations: Thoughts on a Micro-Foundations Project for Strategic Management and Organizational Analysis

2006-3: Volker Mahnke, Torben Pedersen \& Markus Venzin: Does Knowledge Sharing 
Pay? An MNC Subsidiary Perspective on Knowledge Outflows

2006-4: Torben Pedersen: Determining Factors of Subsidiary Development

2006-5 Ibuki Ishikawa: The Source of Competitive Advantage and Entrepreneurial Judgment in the RBV: Insights from the Austrian School Perspective

2006-6 Nicolai J. Foss \& Ibuki Ishikawa: Towards a Dynamic Resource-Based View: Insights from Austrian Capital and Entrepreneurship Theory

2006-7 Kirsten Foss \& Nicolai J. Foss: Entrepreneurship, Transaction Costs, and Resource Attributes

2006-8 Kirsten Foss, Nicolai J. Foss \& Peter G. Klein: Original and Derived Judgement: An Entrepreneurial Theory of Economic Organization

2006-9 Mia Reinholt: No More Polarization, Please! Towards a More Nuanced Perspective on Motivation in Organizations

2006-10 Angelika Lindstrand, Sara Melen \& Emilia Rovira: Turning social capital into business? A study of Swedish biotech firms' international expansion

2006-11 Christian Geisler Asmussen, Torben Pedersen \& Charles Dhanaraj: Evolution of Subsidiary Competences: Extending the Diamond Network Model

2006-12 John Holt, William R. Purcell, Sidney J. Gray \& Torben Pedersen: Decision Factors Influencing MNEs Regional Headquarters Location Selection Strategies

2006-13 Peter Maskell, Torben Pedersen, Bent Petersen \& Jens Dick-Nielsen: Learning Paths to Offshore Outsourcing - From Cost Reduction to Knowledge Seeking

2006-14 Christian Geisler Asmussen: Local, Regional or Global? Quantifying MNC Geographic Scope

2006-15 Christian Bjørnskov \& Nicolai J. Foss: Economic Freedom and Entrepreneurial Activity: Some Cross-Country Evidence

2006-16 Nicolai J. Foss \& Giampaolo Garzarelli: Institutions as Knowledge Capital: Ludwig M. Lachmann's Interpretative Institutionalism

2006-17 Koen H. Heimriks \& Jeffrey J. Reuer: How to Build Alliance Capabilities

2006-18 Nicolai J. Foss, Peter G. Klein, Yasemin Y. Kor \& Joseph T. Mahoney: Entrepreneurship, Subjectivism, and the Resource - Based View: Towards a New Synthesis

2006-19 Steven Globerman \& Bo B. Nielsen: Equity Versus Non-Equity International Strategic Alliances: The Role of Host Country Governance

\section{7}

2007-1 Peter Abell, Teppo Felin \& Nicolai J. Foss: Building Micro-Foundations for the Routines, Capabilities, and Performance Links 
2007-2 Michael W. Hansen, Torben Pedersen \& Bent Petersen: MNC Strategies and Linkage Effects in Developing Countries

2007-3 Niron Hashai, Christian G. Asmussen, Gabriel R.G. Benito \& Bent Petersen: Predicting the Diversity of Foreign Entry Modes

2007-4 Peter D. Ørberg Jensen \& Torben Pedersen: Whether and What to Offshore?

2007-5 Ram Mudambi \& Torben Pedersen: Agency Theory and Resource Dependency Theory: Complementary Explanations for Subsidiary Power in Multinational Corporations

2007-6 Nicolai J. Foss: Strategic Belief Management

2007-7 Nicolai J. Foss: Theory of Science Perspectives on Strategic Management Research: Debates and a Novel View

2007-8 Dana B. Minbaeva: HRM Practices and Knowledge Transfer in MNCs

2007-9 Nicolai J. Foss: Knowledge Governance in a Dynamic Global Context: The Center for Strategic Management and Globalization at the Copenhagen Business School

2007-10 Paola Gritti \& Nicolai J. Foss: Customer Satisfaction and Competencies: An Econometric Study of an Italian Bank

2007-11 Nicolai J. Foss \& Peter G. Klein: Organizational Governance

2007-12 Torben Juul Andersen \& Bo Berhard Nielsen: The Effective Ambidextrous Organization: A Model of Integrative Strategy Making Processes.

\section{8}

2008-1 Kirsten Foss \& Nicolai J. Foss: Managerial Authority When Knowledge is Distributed: A Knowledge Governance Perspective

2008-2 Nicolai J. Foss: Human Capital and Transaction Cost Economics.

2008-3 Nicolai J. Foss \& Peter G. Klein: Entrepreneurship and Heterogeneous Capital.

2008-4 Nicolai J. Foss \& Peter G. Klein: The Need for an Entrepreneurial Theory of the Firm.

2008-5 Nicolai J. Foss \& Peter G. Klein: Entrepreneurship: From Opportunity Discovery to Judgment.

2008-6 Mie Harder: How do Rewards and Management Styles Influence the Motivation to Share Knowledge?

2008-7 Bent Petersen, Lawrence S. Welch \& Gabriel R.G. Benito: Managing the Internalisation Process - A Theoretical Perspective. 